\title{
MODELLING OF INVESTMENT SUPPORT OF USE OF RESOURCE POTENTIAL OF AGRICULTURAL ENTERPRISES
}

\author{
Volodymyr Kharchenko, PhD, Associate Professor'; Hanna Kharchenko, PhD, \\ Associate Professor ${ }^{2}$
}

${ }^{1}$ Faculty of Information Technologies, National University of Life and Environmental Sciences of Ukraine

${ }^{2}$ Faculty of Agricultural Management, National University of Life and Environmental Sciences of Ukraine

\begin{abstract}
In the study the features and dynamics of investment support of Ukrainian agricultural enterprises are investigated. It concerns estimated investment in fixed assets of Ukrainian agrarian enterprises by sources of financing. It is proved that investment support is the most important prerequisite for the effective functioning and development of agricultural enterprises, as it contributes to an increase in resource potential, thus increasing industry efficiency, strengthening the country's food security, creating preconditions for the development of the social sphere and increasing soil fertility. The main problems of enticing investments in the agrarian sphere are considered. Integral indicators of ensuring and efficiency of the use of resources in agricultural production is calculated. Modelling of investment support for the use of resource potential of agricultural enterprises is carried out. The optimal directions of increase of investment support of use of resource potential of Ukrainian agricultural enterprises are offered.
\end{abstract}

Keywords: modelling, investment support, capital investment, resource potential, agricultural enterprise JEL codes: Q14, Q16, O31

\section{INTRODUCTION}

Today, one of the main tasks of the Ukrainian economy should be to ensure sustainable economic growth. This is not only a quantitative increase in gross agricultural production, but above all an increase in the quantity of high-quality food products per capita. Implementation of the necessary economic and organizational measures to increase the level of resource potential of agricultural production is impossible without the use of economic and mathematical modelling.

The purpose of the article is to investigate the investment support of the use of resource potential of agrarian formations on the basis of mathematical modelling.

\section{THEORETICAL BACKGROUND}

The issue of attracting investments in the agrarian sector of the economy and investment support for the economic development of agricultural enterprises is investigated in the works of famous economists, in particular V. Andriychuk, M. Demyanenko, S. Kvasha, M. Kisil, Yu. Lupenko, V. Mesel-Veselyak, and others. However, some issues of investment support for the economic development of agricultural enter-

${ }^{1}$ Corresponding author: Heroyiv Oborony 16a, 03041 Kyiv, Ukraine, vkharchenko@nubip.edu.ua, +38(050) 1717528

${ }^{2}$ Corresponding author: Heroyiv Oborony 11, 03041 Kyiv, Ukraine, kharchenko.a.a@nubip.edu.ua, +38(097) 3437281 
prises remain insufficiently studied and require further research.

\section{MATERIALS AND METHODS}

The methodological basis of this scientific research is the scientific position and mathematical mechanism of system analysis, economic-mathematical modelling and multidimensional statistical analysis. An index method was used in the article to determine the comprehensive impact of a set of factors on the efficiency of the use of resources in domestic agricultural enterprises. In order to determine the rating assessment of the efficiency of farming of domestic agrarian formations, integral indicators were found across Ukrainian regions.

In the first stage, the primary indexes of the ratio of indicators of the regions to the Ukrainian average are calculated according to the following formula (1):

$$
I_{i j}=\frac{x_{i j}}{\overline{x_{i}}}
$$

where:

$I_{i j} \quad$ - the primary index of the integral index $j$-th region, determined on the $i$-th sign;

$x_{i j}$ - the absolute value of the $i$-th indicator of $j$-th region;

$\overline{x_{i}}$ - the average value of the $i$-th indicator in the Ukraine.

In the next stage, the integral indicator of the estimation of the efficiency of management of agrarian formations was calculated with the formula (2):

$$
I P_{j}=\sqrt[n]{\prod_{i=1}^{n}\left(\frac{x_{i j}}{\overline{x_{i}}}\right)}
$$

where:

$I P_{j}$ - the integral index of the estimation of the efficiency of agrarian formation management in the $j$-th region of the Ukraine.

The calculation of integrated indices for the estimation of the efficiency of production and economic activity of domestic agricultural enterprises makes it possible to compare investigated regions providing resources and efficiency of resource use.

\section{RESULTS AND DISCUSSION}

Increasing the level of innovation and investment provisions of the resource potential of agricultural enterprises in the Ukraine contributes to an increase in the volumes of agrarian production and improves its quality, thus gaining competitive advantages, increasing the efficiency of the industry, and increasing food security of the country (Hudzynskyi, 2013). Formation of opportunities for investment activity of enterprises takes place at the expense of different resources, but the main source of financing of investments in fixed assets in agricultural enterprises is own funds, received as a result of economic activity and at the expense of depreciation deductions. It is their own investment resources through profitable business activities which constitute a stable source and is a prerequisite for the investment process (Lupenko et al., 2014).

Domestic agricultural enterprises have potential for increasing agricultural production and increasing foreign economic potential, which requires constant attraction of investments (Table 1). For most domestic agricultural enterprises, the source of investment is own funds (depreciation, profit).

At the same time, in 2016, agriculture was in fact the only type of economic activity, whereby, compared with 2013, investments increased by almost $34 \%$. In fact, agriculture in the Ukraine is now an industry in which investments are currently developing at the fastest rate. Sufficient investment support for agriculture in the Ukraine will increase the level of resource potential of agricultural enterprises. Accordingly, the modelling of investment support for the use of the resource potential of agricultural enterprises was carried out.

The development of innovation and investment processes in the agroindustrial complex is faced with the following problems: low level of agricultural machinery; insufficient modern level of agrotechnologies, which does not provide ecologically safe and economically effective results of agricultural activity; significant level of cultivation and degradation of agricultural land; lack of state support for breeding systems in livestock; insufficiency of scientific support of activity of certain branches of the agrarian and 
Proceedings of the 2018 International Scientific Conference 'Economic Sciences for Agribusiness and Rural Economy' No 1, Warsaw, 7-8 June 2018, pp. 321-326

Table 1. The dynamics of investment in fixed assets of agricultural enterprises in Ukraine

\begin{tabular}{|l|c|c|c|c|c|c|c|c|}
\hline Specification & 2010 & 2011 & 2012 & 2013 & 2014 & 2015 & 2016 & $\begin{array}{c}2016 \text { to } 2010 \\
\text { (\%) }\end{array}$ \\
\hline Total (UAH billions) & 189.1 & 259.9 & 293.7 & 267.7 & 219.4 & 273.1 & 359.2 & 190 \\
\hline Agriculture (UAH billions) & 11.6 & 17.0 & 19.4 & 19.1 & 18.8 & 30.2 & 49.7 & in 4 times \\
\hline Specific gravity of agriculture (\%) & 6.0 & 6.5 & 6.5 & 7.0 & 8.4 & 10.7 & 13.9 & $\times$ \\
\hline
\end{tabular}

Source: State Statistics Service of the Ukraine (2017).

industrial complex as well as a lack of specialized financial and credit infrastructure focused on servicing agricultural production (Ilychuk and Shpomer, 2017).

One of the main objects of economic-mathematical modelling is to increase the efficiency of the formation and use of the resource potential of agricultural enterprises in the Ukraine. Nowadays, a particularly important issue is the strengthening of the level of resource potential of agrarian units. In market conditions of the transformation of agricultural production, the use of the correlation-regression analysis revealed the extent of the influence of certain factors on the resource potential of agricultural enterprises. In addition, the index method and cluster analysis were used in the study to determine the comprehensive impact of a combination of factors on resource provision, resource efficiency and agricultural production efficiency of domestic agrarian formations (Kharchenko and Kharchenko, 2015a, b).

Thus, for the purpose of determining the rating assessment of the efficiency of the management of domestic agrarian formations, integral indicators were found across the regions of the Ukraine. The distribution of integral indicators in three groups is presented in Table 2.

Table 2. Integral indicators of ensuring, efficiency of resource use and efficiency of agricultural production

\begin{tabular}{|c|c|}
\hline Group name & Indicators \\
\hline $\begin{array}{l}\text { I group } \\
\text { Indicators of resource provision }\end{array}$ & $\begin{array}{l}\text { 1. The area of agricultural land (thous. ha) } \\
\text { 2. Normative monetary valuation of } 1 \text { ha as of } 1 \text { January } 2016 \\
\text { 3. Land provision of } 1 \text { employee (ha agricultural land) } \\
\text { 4. Conditional heads of hectares of } 100 \text { ha agricultural land (UAH) } \\
\text { 5. Capital investment per } 1 \text { ha (UAH) } \\
\text { 6. Tractors per } 1,000 \text { ha of arable land (pcs.) } \\
\text { 7. Power capacity per } 1 \text { ha agricultural land (thous. } \mathrm{kWh)}\end{array}$ \\
\hline $\begin{array}{l}\text { II group } \\
\text { Indicators of resource efficiency }\end{array}$ & $\begin{array}{l}\text { 1. Production of gross output per } 1 \text { ha of agricultural land (UAH) } \\
\text { 2. Gross output per } 1 \text { employed in agricultural production (UAH) } \\
\text { 3. Production of gross output at } 1 \text { cost (UAH) } \\
\text { 4. Production of gross livestock production per } 1 \text { conditional head (UAH) } \\
\text { 5. Grain production per } 1 \text { harvester (centners) }\end{array}$ \\
\hline $\begin{array}{l}\text { III group } \\
\text { Indicators of agricultural production } \\
\text { efficiency }\end{array}$ & $\begin{array}{l}\text { 1. Profit million (UAH) } \\
\text { 2. Profit per } 1 \text { ha of agricultural land (UAH) } \\
\text { 3. Profit per } 1 \text { employee (thous. UAH) } \\
\text { 4. Profitability (\%) } \\
\text { 5. Payment of labour } 1 \text { employee (UAH) }\end{array}$ \\
\hline
\end{tabular}

Source: authors' calculations. 
Proceedings of the 2018 International Scientific Conference 'Economic Sciences for Agribusiness and Rural Economy' No 1, Warsaw, 7-8 June 2018, pp. 321-326

The next step is calculating the integral index of the estimation of the efficiency of agrarian formation management. Analysis of regional differences based on the calculation of integral indicators allowed regionalizing regions and determining the ranking of regions by selected indicator blocks.

Thus, it was established that according to the rating of regions of the Ukraine, by providing an integrated index, the following regions are provided: Vinnytskiy - 1.417; Kyevskiy - 1.299; Cherkaskiy - 1.175 and Ivano-Frankivskiy - 1.173 have a high level of provision. Regions such as Lvivskiy - 1.135; Dnipropetrovskiy -1.101 ; Poltavskiy -1.081 ; Volynskiy region
- 1.052; Khmelnytskiy - 1.032; Kharkivskiy - 1.010; Khersonskiy - 1.005; Rivnenskiy -0.915 and Ternopil -0.913 with the use of the integral index, has an average level of provision of resources. The remaining regions have a low level of resource provisions (Fig. 1).

The next step was to study the ranking of Ukrainian regions with the use of the integral indicator of resource use (Fig. 2). The results of the calculations showed that Lvivskiy - 1.270; Ivano-Frankivskiy 1.224; Khmelnytskiy - 1.205; Ternopilskiy - 1.171; Cherkaskiy - 1.141; Sumskiy - 1.120; Vinnitskiy - 1.197; Kharkivskiy - 1.112 and Rivnenskiy - 1.089 regions have a high integrated resource use index.

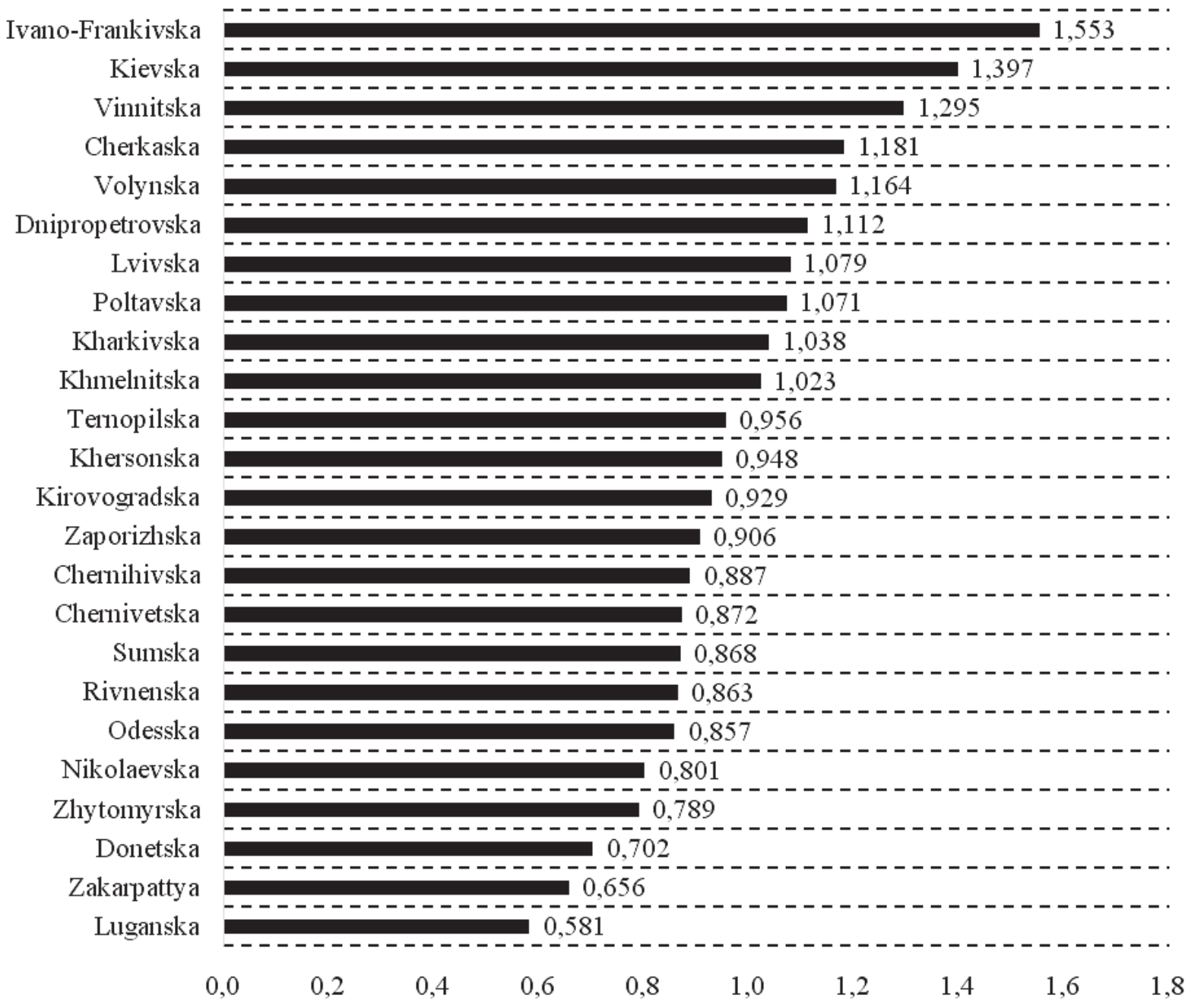

Figure 1. Rating of the Ukraine's regions by integrated provision resource index Source: authors' calculations. 
As for the integrated index of indicators of agricultural production efficiency, the Ivano-Frankivskiy region has the highest rating of 2.169. This is justified primarily by the small area of sowing and livestock specialization in the region. Also, the following regions have high ratings: Khmelnytskiy -1.762 and Lvivskiy -1.750 .

The results of calculating integral indices in regions of the Ukraine in graphical form are shown in Figure 2.

The regions with the lowest level of resource availability, the efficiency of using these resources and the efficiency of agricultural production are located closest to the centre of the diagram.

Such regions as Donetskiy, Zhytomyrskiy, Chernivtskiy and Chernihivskiy have low available potential and low indicators of economic efficiency. Unlike the above regions, Vinnytskiy, Ivano-Frankivskiy, Kyivskiy and Cherkaskiy regions have a high level of available potential with an average level of agricultural production efficiency. In turn, regions such as
Vinnytskiy, Ivano-Frankivskiy, Lvivskiy, Rivnenskiy, Sumskiy, Ternopilskiy, Kharkivskiy, Khmelnytskiy and Cherkaskiy have a high level of resource use.

It should be noted that the rational use of resources depends on a number of factors such as: a rational ratio of elements in the structure of resource potential, the management system and the introduction of resource-saving technologies.

Regarding the effective formation of the resource potential of domestic agrarian units, it is expedient simultaneously with the increase of cost indicators to improve its qualitative composition.

Also, in order to ensure an effective process for the formation and use of resource potential in its organization, it is necessary to take into account all the factors influencing it and determine the effectiveness of this potential.

Research has shown that nowadays one of the main factors of effective activity of agricultural enterprises, which allows to achieve extended reproduction, is innovation and investment support.

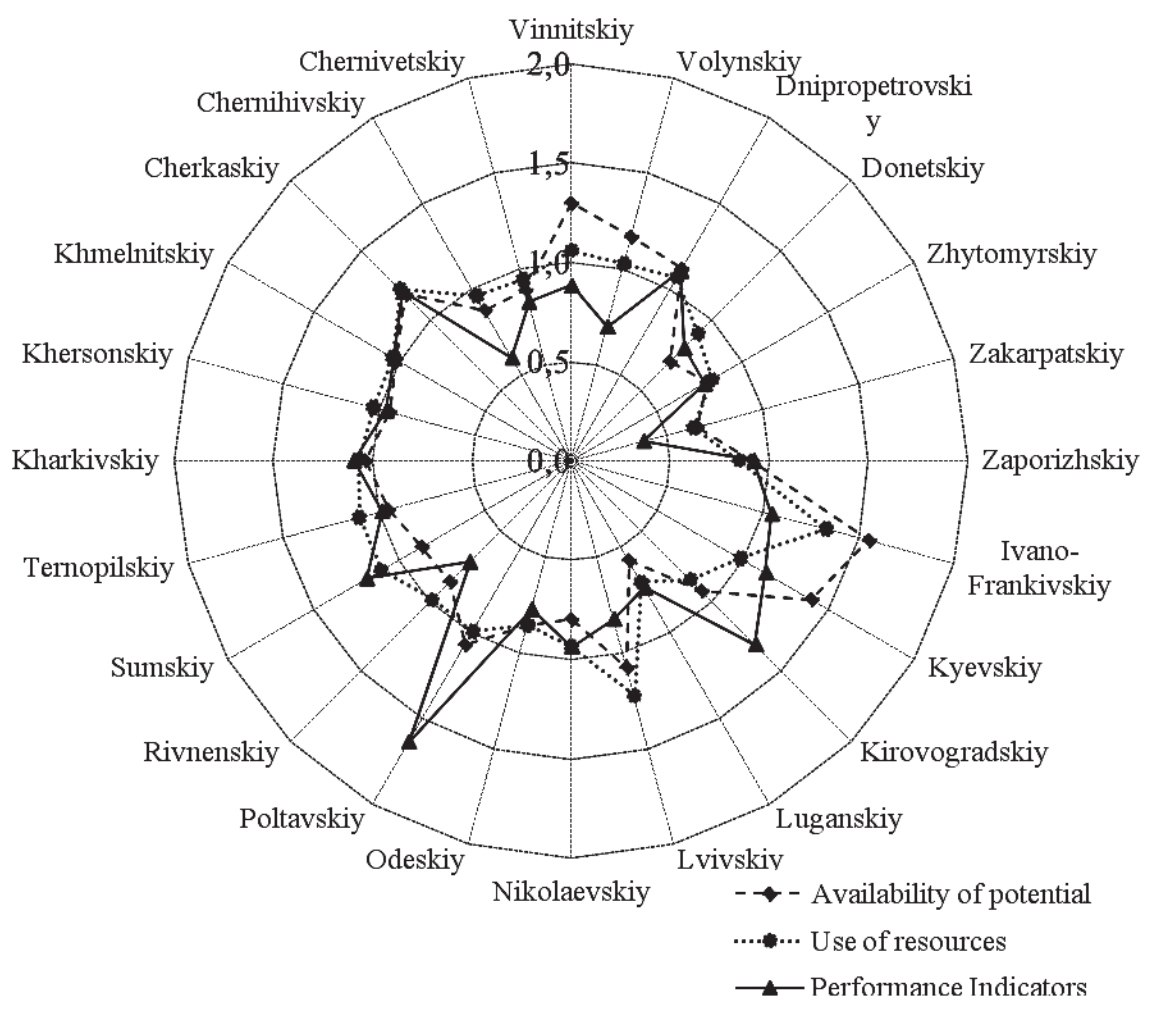

Figure 2. Results of calculation of integral indexes Source: authors' calculations. 
It was established that the innovative and investment support of efficient activity of agricultural enterprises is aimed at satisfying the food needs of the population by improving the land as a natural resource, creating new varieties of plants and breeds of animals, updating the material and technical base as well as ensuring the production of highly skilled personnel, etc.

Consequently, sufficient innovation and investment support for agricultural production will ensure a high level of competitiveness of agrarian units. Also, an effective innovation system, both on a micro-and macro-level, depends on the optimal information infrastructure and the links between the participants in the innovation process (Ermakov and Kharchenko, 2014).

Therefore, in order to successfully solve these goals, it is necessary to introduce an effective system of innovation and investment which provides the resource potential of agrarian formations that rationally combines material, organizational and intellectual aspects, the creation of favourable conditions for the efficient development of crop and livestock sectors with the attraction of public funds, credit mechanisms and investment capital etc.

\section{CONCLUSIONS}

It is believed that the main strategic directions of innovation and investment provision of agricultural potential of agricultural enterprises are: the implementation of scientific support of the agricultural sector, the development and implementation of an effective system of agro-technical measures, the creation of high-yield hybrids of plant varieties, the introduction of new approaches to soil cultivation, the revival and stabilization of the livestock population and the selection and training of highly skilled personnel.
Consequently, the realization of strategic tasks in the field of innovation and investment provision of agricultural enterprises' resource potential is a prerequisite for ensuring their effective long-term competitive advantages, increasing the scientific and technical level of production, and the efficiency of the use of resources, which will, in the long-run will promote the sustainable development of agricultural production.

\section{REFERENCES}

1. Ermakov, O., Kharchenko, H. (2014). Agri-food potential of agricultural enterprises: formation and efficiency of use. Kyiv.

2. Hudzynskyi, O. (2013). Formation of system investment support strategic development of agricultural enterprises. Collection of scientific works of Tauride Agrotechnological University, 4, pp. 5-8.

3. Ilchuk, V., Shpomer, T. (2017). Innovation and investment activity of AIC: current state and problems of development. Agricultural and Resource Economics: International Scientific E-Journal, 3 (1), pp. 108-118 .

4. Kharchenko, V., Kharchenko, H. (2015a). Innovative and investment support for the formation of the agricultural potential of agricultural enterprises. Kyiv.

5. Kharchenko, V., Kharchenko, H. (2015b). Optimization of the use of productive resources of agrarian business. Journal Actual Problems of Economics, 10 (172), pp. 458-465.

6. Lupenko, Y., Malik, M., Shpiculyak, O. et al. (2014). Innovative support for the development of agriculture in Ukraine: problems and prospects. Kyiv.

7. Sabluk, P., Shpykuliak, O., Kurylo, L. et al. (2010). Innovative activity in the agricultural sector: institutional aspect. NSC IAE, Kyiv.

8. State Statistics Service of Ukraine Agricultural of Ukraine (2017). Statistical yearbook 2016. Kyiv. 